\title{
Retorik, İkna ve Tasarım Jürisi
}

Seçil Toros*

Toros, S. (2020). Retorik, İkna ve Tasarım Jürisi. YEDİ, 23, 11-20, doi: $10.17484 /$ yedi.598114

Araştırma Makale / Research Article

özet

Bu çalışmada, tasarım eğitiminde sembolik öneme sahip ve öğrenmenin vazgeçilmez bir parçası olan tasarım jürilerinde, öğrencilerin kullanması için bir 'retorik model' önerilmektedir. Bu özgün modelde öğrencilerin tasarım fikirlerini anlatmaları ve projelerini jüri üyeleri önünde savunmaları için sistemli aşamalar ve öneriler bulunmaktadır. Aşamalar jüri süreci ve akışı dikkate alınarak planlanmış ve öneriler Aristoteles’in retorik teorisi üzerine yapılandırılmıştır. Hem sözle hem de görsel iletişim öğelerinin planlanmasına ilişkin model, öğrencilere rehber olacak ve etkili sunum yapmalarında fayda sağlayacaktır.

Anahtar Kelimeler: Tasarım jürisi, iletişim, iletişim tasarımı, ikna, retorik.

\section{Rhetoric, Persuasion and Design Jury}

Abstract

In this study, a 'rhetorical model' is proposed for the use of students in design juries which are symbolic and indispensable learning events in design education. This original model offers systematic steps and suggestions for students to present and defend their design ideas in front of the jury. The stages were planned considering the jury process and communication flow, and the recommendations were based on Aristoteles' rhetorical theory. This unique model will guide the students to plan both verbal and visual communication elements and also help them to make effective presentations.

Keywords: Design jury, communication, communication design, persuasion, rhetoric. 


\section{Giriş}

Tasarım jürileri mimarlı, moda, grafik ve endüstri ürünleri tasarımı gibi birçok alanda ritüel haline gelmiş etkinliklerdir. Jüriler, tasarım projelerinin değerlendirilmesi ve uzman geribildirimleri ile geliştirilmesi için ortam sağlarken aynı zamanda profesyonel hayatın bir provası niteliğini taşır. Öğrenciler, alanlarında uzman ve üretken kişilerle tanışma ve onların tasarımları hakkındaki eleştirilerinden faydalanma fırsatı bulurlar. Bu değerli süreç, tasarım eğitiminde bireysel ve kolektif öğrenmenin bir parçası olarak kabul edilir (Frederickson, 1990). Ayrıca jüriler, öğrencilerin kendi tasarımcı kimliklerini oluşturmaları bakımından da faydalı ve öğrenci merkezli bir etkinlik olarak görülür (Ilgaz, 2009, s. 75; Webster, 2006). Sözü edilen öğrenme ve mesleki kazanımların yanında, tasarım jürileri, öğrencilerin not olarak değerlendirilmesinde etkili ve yaygın bir araç olarak kullanılır (Gurel ve Basa, 2004) ve bu son işlev, özellikle öğrenciler için büyük önem taşır.

Tasarım jürilerinde öğrenciler alanda uzman akademisyen ve deneyimli profesyonellerin önünde projelerini anlatır ve tasarım fikirlerini savunmaya çalışırlar. İletişimin diğer tarafında bulunan jüri üyeleri ${ }^{1}$ ise hem projeler üzerinde eleştirel bakış açısı geliştirmeye hem de öğrencileri değerlendirmeye çalışırlar. Bu kurgu iki güç arasındaki dengesiz ilişki ile şekillen ve profesyonellerin hegemonyasında geçen karmaşık bir süreçtir (Webster, 2007). $\mathrm{Bu}$ ortamda güç, eleştiri getirme ve tartışma (münazara) alanlarına ilişkin eşitsizliklerin jüri çıktıları üzerindeki olumsuz etkileri olabilmektedir (Ilgaz, 2009). Söz konusu olumsuz etkilerin başında öğrenciler üzerinde oluşan baskı ve başarmayı zorlaştıran heyecan gelmektedir.

Stüdyo derslerinin ölçme ve değerlendirmeile ilgiliönemli ve son aşaması olan tasarım jürilerinde öğrencilerin özgün fikirlerini anlatabilmeleri ve savunabilmeleri gerekir. Bu ikna sürecinde öğrenci, jüri üyelerinden farklı yorumlarla karşılaşır ve bunlar içinden bazılarını tasarımlarını güçlendirmek adına projeye adapte etmeyi başarırken, bazen de eleştirilerin altında ezilerek tasarım fikirlerinin tahribata uğramasını izler. Bu gibi durumlarda jüri öğrenciler tarafından yıkıcı, eleştirel ve hatta düşmanca bir ortam olarak algılanır (Frederickson, 1990). Öğrenciler, performansının değerlendirildiği 10 ila

1 Jüri, söz konusu projenin yürütüldüğü stüdyo dersini yürüten öğretim elemanları ve dışarıdan gelen uzmanlardan oluşan çoğunlukla kalabalık bir gruptur.
20 dakikalık sürede kendi yapıtlarını hem anlatmak hem de etkili biçimde savunmak baskısını yoğun biçimde hissederler. Bu nedenle iletişim ve ikna becerisi tasarım jürilerinde hayati önem taşır.

Etkileyici ve ikna edici iletişim için sunum yapan öğrencinin düzgün ve etkili sözel sunuş sergilemesi; tasarımın özgün konseptini, amacını ve tasarımın gelişim sürecini anlatması ve dahası farklı tasarım deneyimlerine ve felsefelerine sahip jüri üyelerinin yorum ve eleştirilerine cevap verebilmesi ve projesini bu cevaplar ile savunması gerekir. Deneyimsiz ve henüz mesleki bilgi ve becerilerini tam manada geliştirememiş olan öğrenciler için bunu yapmak hiç de kolay değildir. Kötü bir tasarım projesi iyi bir sunum ile kurtarılamayabilir ancak kötü bir sunum şüphesiz iyi bir projeyi mahvedecektir.

Özetle, tasarım öğrencileri için her bir jüri sunumu öğrencilikleri ve kariyerleri ile ilgili önemli bir basamaktır: mesleki başarının ya da başarısızlığın en büyük göstergesidir. Sunum, belki de aylar süren, tasarım sürecinin sonucudur; ödülü ya da cezasıdır. Bu nedenle öğrenciler jüri sunumlarında oldukça heyecanlıdır. Heyecanlı olmak ile ilgili sorun yoktur, zira önemsenmesi ve ciddiye alınması gereken zorlu ve zorunlu bir süreçtir; önemli olan heyecan ve başarma baskısının üstesinden gelebilmektir. Bunu başarabilmek için ise hem görsel hem de sözel sunumun tutarlı ve etkili biçimde hazırlanması gerekmektedir.

Yukarıda açıklanan amaç doğrultusunda bu çalışmada tasarım eğitiminde sembolik öneme sahip ve öğrenmenin vaz geçilmez bir parçası olarak görülen tasarım jürilerinde öğrencilerin kullanması için 'retorik model' önerilmektedir. Hem sözel hem de görsel iletişim öğelerinin planlanmasına ilişkin model, öğrencilere rehber olacak ve etkili sunum yapmalarında fayda sağlayacaktır. Bu özgün modelde öğrencilerin tasarım fikirlerini anlatmaları ve projelerini jüri üyeleri önünde savunmaları için sistemli aşamalar ve öneriler bulunmaktadır. Aşamalar jüri süreci ve akışı dikkate alınarak planlanmış ve öneriler de Aristoteles'in retorik teorisi üzerine yapılandırılmıştır.

İkna iletişimi ve bu bağlamda Aristoteles'in retorik çalışması, başta hukuk olmak üzere, halkla ilişkiler, reklamcılık ve siyaset bilimi gibi akademik alanlarda başlıca ele alınan konular arasında bulunsa da mimarlık, grafik, moda ve endüstri ürünleri tasarımı eğitiminde ve alan yazınlarında yeterli ilgiyi görmemektedir. Bu kapsamda taran akademik çalışmalarda jüri iletişimi ve bu süreçte yaşanan sorunların 
ele alındığı (Frederickson, 1990; Ilgaz ve Korkut, 2013), bu iletişim kapsamında güç ilişkilerine odaklanıldığı (Webster, 2006) görülmektedir. Buna ek olarak Daroda (2011) rekabetçi ortamda, mimarlık ve tasarım öğrencilerinin, ikna edici iletişim ve etkili konuşma tekniklerini öğrenmeleri gerektiğine de değinmektedir. Ancak öğrencilerin projelerini savunurken ihtiyaç duydukları sözel ve görsel iletişim tekniklerine yer veren kapsamlı bir akademik çalışma bulunmamaktadır. Söz konusu boşluğu doldurmak amacıyla hazırlanan bu çalışmanın alana katkı sağlayacağı ve tasarımda ikna ile ilgili yeni araştırmalara zemin oluşturacağı düşünülmektedir.

Makale 'Retorik ve ikna' bölümü altında Aristoteles'in ikna öğeleri olan logos, ethos ve pathosun ayrı ayrı ele alınması ile başlayacaktır. Burada inşa edilen teorik arka plana uygun olarak 'Retorik model' sunulacak ve tasarım jürisi sürecinde temel evreler olarak belirlenen 'Ne yaptım?', 'Neden yaptım?' ve 'Nasıl yaptım?' başlıkları altında kapsamlı biçimde açıklanacaktır. Çalışma, 'Nihai ve genel öneriler' sunulduktan sonra sonuç kısmında yapılacak değerlendirme ve yeni akademik yönlerinin önerilmesi ile sonlanacaktır.

\section{Retorik ve İkna}

Retorik hukuk, iletişim, siyaset ve sanat gibi pek çok alanda sıklıkla kullanılan bir kavramdır. Ortak kabul gören tanımı 'etkili yazı ve söz kullanarak ikna sanatı' olarak özetlenebilir. Kökenleri Antik Yunan düşünürlerine dayanan retorik, günümüzde söz ve yazının ötesinde, mevcut durumu istenilene çevirmeye yarayan her türlü ikna tekniğini kapsamaktadır (Kaufer ve Butler, 2013, s. 20). Görsel ve sözel iletişimin bir arada bulunduğu tasarım jürileri bu tekniklerin birden fazlasının kullanımına sahne olur. Bu teknikleri anlayabilmek için Aristoteles'in retorik teorisine başvurmak ve ikna edici öğeleri tek tek incelemek yerinde olacaktır.

Aristoteles'e göre inandırma ve ikna etme doğuştan gelen bir hediye değildir; retorik yoluyla ulaşılabilir teknik bir kabiliyettir ve bu kabiliyet ikna edici öğelerin gösterilmesi yetisidir (L’Etang, 2002, s. 190). Kanıtlar bir tür gösteri eşliğinde sunulur ve gösteri ne kadar etkileyici olursa insanlar o kadar ikna olurlar. Retorik kanıtlar, ulaşılmak istenen amaca uygun olarak sembollerin kullanımını içerir ve bu semboller aracılı̆̆ ile karşılıklı anlayış geliştirilir. Heath (2004, s. 126), kur yapmaya benzettiği retoriği diğerleriyle birlikte birleştirici görüşlere katılmaya bir çağrı olarak yorumlar. Tasarım jürilerinde de öğrenci, farklı öncelikleri ve beklentileri bulunan jüri üyelerini kendi istediği yöne adapte etmeye çalışır ve bu beceriyi retorik sayesinde geliştirebilir.

Aristoteles (2004, s. 38), retoriğin analizine ilişkin önerdiği yöntemde üç tür inandırma tarzını hesaba katar; ethos, logos ve pathos. 'Ethos' konuşmacının karakteri yani ikna edicinin güvenilirliğine baş vurma, 'logos' mantık yoluyla yani kanıtlarla hakikati gösterme ve 'pathos' duygulara hitap etme yani dinleyiciyi belli bir ruh haline sokarak ikna etmeyi kapsar (McCormack, 2014). Bu bölümün devamında söz konusu öğeler tek tek ele alınacak ve incelenecektir.

\section{Ethos: Konuşmacının Karakteri}

Konuşulanın inanılır olması, konuşanın inanılır olması ile ilişkilidir. İkna konuşmacının söylediği şeylerle gerçekleşse de konuşmacının gösterdiği kişisel iyiliği ve karakteri, sahip olduğu en etkili inandırma yoludur (Aristoteles, 2004, s. 64). Bireyin karakteri daha açı bir ifade ile güvenilirliği retorik sürecin merkezinde bulunur. Konuşmacının karakterine güven aşılayan üç şeyi Aristoteles (2004, s. 98), (1) sağduyu (iyi akıl), (2) iyi ahlaki karakter ve (3) iyi niyet olarak belirlemiştir. Bireyin kendinden ve zekasından başlayan iyiliğin, çevresine ve topluma yayılması beklenmektedir.

Aristoteles'in (Heath, 2004, s. 137-140) retoriğine göre ikna yalnız gösterilen kanıtlarla değil aynı zamanda etik kanıtlarla başarılır. Dinleyenler, konuşmacının kendisinin iyilik ya da kendilerine karşı iyi niyet veya her iki niteliği de sahip olduğuna inanırlarsa, ikna süreci kendiliğinden başlar. Yani söylevcinin iyi olması yeterli değildir; çevresi ve toplum için de en iyiyi talep etmesi ve sözünü bu amaçla söylediğini göstermesi gerekir.

Benzer şekilde Antik Roma'da bir retorik savunucu olan Quintilian2, ideal hatibin (anlatıcı) sahip olması gereken özellikleri şöyle tanımlar: "doğru bir filozof ahlak açısından sağlam, konuşma hakkında bilgili ve her zaman en yüksek için çalışandır" (Heath, 2004, s. 119). Her iki betimlemeden de anlaşılacağı gibi 'iyilik' özelden genele doğru sıralı olarak aranmaktadır. Ayrıca her iki yaklaşımda da iyi karakter bilgelikten kaynaklanmaktadır. Dolayısıyla iknacının her şeyin başında bilgili, donanımlı ve sözüne güvenilir bir kişi olduğunu yansıtması gerekir.

2 Marcus Fabius Quintilianus (MS 100-MS 100), eski Roma'da orta çağ okullarında edebiyat ve retorik konularında eğitim vermiştir. 
Logos: Bir Hakikati Ya Da Sözde Hakikati İnandırıcı Kanıtlar Yoluyla Tanitma

Retorik ilk ortaya atıldığında, bugünkü gibi değerli bir beceri olarak görülmüyordu. Sokrates ve öğrencisi Platon'un, retorik kullanmayı bir akıl oyunu olarak tanımladığı bilinmektedir. Filozoflar bu düzmece yöntem ile başkalarının zaaflarından yararlanıldığını ne bilgi ne de anlam aktarmadan yalnız kanaatler üreterek hakikatler konusunda insanları ikna etmede söz konusu yeteneğin kullanıldığını belirtiyorlardı (L'Etang, 2002, s. 195-198). Ancak Aristoteles'e göre bir retorik, gerçek vaadi bulunmayan ve içi boş kelimelerle ayakta duramaz (Heath, 2004, s. 110). Retorik söz, ya da ifade, kendiliğinden açık olduğu için veya böyle açık ifadeler ile kanıtlanabilir olduğu için inandırıcı ve ikna edicidir.

'The Art of Rhetoric' kitabında Aristoteles, ikna yolu olarak, çeşitli türden kanıtların altında yatan ilkeleri keşfeder. İkna amaçlı retorik uygulaması, kanıtların planlanması ve yaratılması üzerine inşa edilir; bunlar eksiksiz tanıtlar, olasılıklar ve göstergelerdir (Aristoteles, 2004, s. 39).

... diyalektik ve retorik tasımlara ${ }^{3}$ özgü konular, düzenli ya da evrensel Kanıtlama Yollarıla ilgili olduğunu söylediğimiz şeylerdir; yani doğru sorulmuş sorulara, doğal bilimlere, politikaya ve birbiriyle ilişkili olmayan daha birçok şeye ait sorulara aynı şekilde uygulanan kanıt dizeleridir. (Aristoteles, 2004, s. 42)

Kanıtların yaratılması ise bizi dinleyenlerin inanacağı şekilde kabul gören düşüncelerin keşfi ile mümkündür. Bu noktada ne söyleneceğinin bilinmesi yetmez; aynı zamanda doğru bir şekilde söylemelidir. İnandırma bir tür gösteridir ve insanlar bir şeyin gösterildiğini düşündüğü zaman tamamen ikna olurlar (Aristoteles, 2004, s. 35). Fikir ve tasarımlara inandırmak için mantık kullanılmalı ve kurulan mantık açık ve anlaşılır biçimde sergilenmelidir.

Hakikati kabul ettirmek için geçerli, ilgili ve anlaşılır kanıtlar sunulmalıdır: “...çünkü elimizde ne kadar çok güncel kanıt olursa, davamızı o kadar kolay tanıtlarız ve bunlar konuyla ne kadar yakından ilgili olursa, o kadar, sıradan kanıtlar değil de yalnızca o konuşmaya ait kanıtlar oldukları görülür” (Aristoteles, 2004, s.142). Aynı zamanda sunulan her kanıt, hitap edilen toplumun değerlerini taşımalı ve kabul

3 Doğruluğu kabul edilen verilmiş iki önermeden, bu önermelerin içeriğini içinde bulunduran bir üçüncü önerme çıkarma biçimindeki akıl yürütme yolu; örneğin, insanlar ölümlüdür, Sokrates bir insandır, o halde Sokrates ölümlüdür uslamlaması bir tasımdır. ettirilmek istenen fikrin sonucunun iyi olacağına dair şüphe bırakmamalıdır: "Retoriğin verili anlam yaratma ve değer kurma gücüyle yöneticilerine ve diğerlerine değer yüklü seçimleri anlama, eleştirme ve kullanmaları açısından yardım edebilir. Retoriğin mantığı, kolektif çıkarları destekleyen bakış açılarını uygulamak zorunda olan insanların sosyal ve politik ihtiyaçlarına ses verilmesi yeteneğindedir" (Heath, 2004, s. 140).

\section{Pathos: Dinleyiciyi Belli Bir Ruh Haline Sokma}

Konuşmacının itibarı ve güvenilirliği ile mantık yoluyla üretilen kanıtlar bir arada kullanılsa da söylevin sonunda dinleyicilerin ikna olmasına yetmeyebilir. İkna, nihayetinde, zihin ile birlikte duygu durumudur. Aklı ile inanan dinleyici bazen kalbi ile ikna olmayabilir. Tersine eğer konuşma dinleyicide istenilen coşkuları harekete geçirebilirse, inanma dinleyicilerden de gelebilir (Aristoteles, 2004, s. 38).

Coşkular, insanların inançlarını ve yargılarını değiştirebilecek kadar etkili duygulardır. İnsanlar, aynı şeyi (olayı ya da olguyu) dostça ve hoşgörülü duygular taşıdıkları zaman ile öfke ve düşmanlık duyguları ile yüklü oldukları zamandan daha farklı algılar ve yargılarlar (Aristoteles, 2004, s. 98). Dolayısıyla karşılıklı anlayış ve düşünce birliği geliştirebilmek için duygusal dayanışma hissini yaratmak gerekir. Retorik bazen dinleyicilere duymak istediklerini söyleyerek hoşnut ederken bazen de hoşnutluğa meydan okur; konuşmacı her iki tekniği de kendi çıkarları doğrultusunda kullanmalıdır (McCormack, 2014).

Dinleyicide belli bir ruh hali yaratma ancak dinleyiciyi iyi tanımakla mümkündür. Aristoteles öfke örneği üzerinden izleyicilerde coşku yaratabilmek için bilinmesi gereken üç unsuru şöyle sıralar: (1) öfkeli dinleyicilerin nasıl bir ruh hali içinde olduklarını, (2) genellikle öfkelendikleri kişilerin kimler olduğunu ve (3) onlara hangi sebeplerle öfkelendiklerini saptamak (Aristoteles, 2004, s. 98). Aristoteles bu maddelerden bir veya iki tanesinin yanıtını bilmenin yeterli olmayacağını, üç sorunun cevabının birden bilinmesi gerektiğini söylemektedir. Benzer bir mantık ile tasarım jürilerinde şu üç soru geçerli olabilir 1) jüri nasıl bir ruh hali içindedir? 2) genellikle onaylayacakları ve coşkulanacakları yaklaşımlar neler olabilir? 3) hangi nedenle coşku duyarlar?

Aristoteles'in retorik anlayışında dinleyici bir topluluk olarak ele alınır. Toplumda çoklu kamular ve çoklu dinleyiciler vardır. Bireysel durumların çeşitliliğinden dolayı, belli bireylere değil belirli tipten insanlara olası görünen şeylerle ilgilenilir 
(Aristoteles, 2004, s. 40). Bu görüşten hareketle öğrencilerin, tasarım jürilerinde yer alan üyelerin profesyonellerden ve akademisyenlerden oluştuğunu hesaba katarak ortak yönelimleri keşfetmeleri yerinde olacaktır. Bunlar için çağdaş tasarım yaklaşımlarını, mesleki etik değerleri ve tasarımcıların sıkça kullandıkları kültürel değerleri iyi bilmeleri gerekir. Bunlara ek olarak çağdaş iletişimde kullanılan psikolojik ve sosyolojik anlayışı; kişilik türleri, ikna edicilik ve ikna etkilerinin güçlendirilmesi için farklı duyguların yaratılması konuları da incelenebilir.

\section{Retorik Model}

Jüri, bir öğrenci ya da öğrenci grubu ile jüri üyeleri arasında gerçekleşen karşılıklı iletişimin sahnesidir. Bu gösteride öğrenci söze başlar ve kendi tasarımını öncelikle tanıtmaya ve sonrasında yapılan projenin değerliliği konusunda jüriyi ikna etmeye çalışır. Karşısında ise konusunda çeşitli deneyimlere ve bilgi donanımına sahip uzmanlar bulunmaktadır ve bireysel eleştirilerle katkılarını sunmak için oradırlar. Bu senaryoda öğrenci, jüri üyelerinden gelebilecek farklı bakış açılarını hesaba katmak ve bunları kestirmek zorundadır. Başarılı olabilmek için süreci olabildiğince yönlendirmeli, jüriyi arzu ettiği bakış açıcısına sokarak olumlu ve yapıcı diyaloğun yolunu inşa etmelidir. Bunun için çalışmanın bu bölümünde retorik tekniklerine dayanan tasarım jürisi modeli önerilmektedir. Tablo 1'de görülen modelde jüri süreci sistemli bir şekilde planlanmıştır. Tümden gelim yöntemini benimseyen anlatıda sırsıyla uygulanması gereken üç aşama bulunmaktadır: 1) Ne yaptım 2) Neden Yaptım ve 3) Nasıl Yaptım

Tablo 1. Retorik Model

\begin{tabular}{|c|c|c|c|}
\hline Jüri Süreci & Ethos & Logos & Pathos \\
\hline Ne Yaptım & Ne yaptığımı biliyorum & Açıkladım & Değerli bir fikir sunuyorum \\
\hline $\begin{array}{l}\text { Neden } \\
\text { Yaptim }\end{array}$ & $\begin{array}{l}\text { Sorunların farkındayım } \\
\text { ye herkes için iyi olanı } \\
\text { istiyorum }\end{array}$ & $\begin{array}{l}\text { Kanitlar ile } \\
\text { gösteriyorum }\end{array}$ & Bu tasarıma ihtiyaç var \\
\hline Nasil Yaptım & $\begin{array}{l}\text { Sorumluluklarım1 biliyorum } \\
\text { ve yerine getirdim }\end{array}$ & Akklc1 çözüm budur & Bunu başarabiliriz \\
\hline
\end{tabular}

Şimdi, yukarıda önerilen retorik modelin üç basamağı hem sözel hem de görsel ikna kabiliyetinin geliştirilmesi bağlamında açıklanacaktır.

\section{Ne Yaptım?}

Öğrenciler haftalar ve belki de aylar süren emeklerinin çıktısını sunmak ve hak ettiklerini düşündükleri sonucu alabilmek için jürinin karşısına çıkarlar. Tasarım sürecinde sarf ettikleri eforu ve karşılaştıkları zorlukları anlatmak isterler. Bu da çoğunlukla uzun ve öznel bir giriş yapmalarına neden olur. Öğrenciler, bazı durumlarda, aslında jürinin pek de ilgilenmediği duygusal ya da bireysel yaşanmışlıkları paylaşarak empati geliştirilmeye çalışırlar. Sunuma, tasarım sürecinin en başından en sonuna kadar başlarından geçenleri anlatarak ve genellikle de olumsuzluklara ve çekilen acılara vurgu yaparak başlarlar.

Jüri ise genellikle öğrenciler ile aynı ruh durumunda değildir; sunumuna başlayan öğrenci ve projesi o gün izleyecekleri onlarcasından biridir. Sunumun hemen başında jüri üyeleri bir yandan hali hazırda aslı paftalar arasında göz gezdirirken bir yandan da öğrenciyi dinlemekte ve bir an önce özgün tasarım fikrini anlayama çalışmaktadır. Bu birkaç dakikalık sürede jüri üyeleri istisnasız aynı sorunun cevabını ararlar: 'Ne yapmış?'

Webster'ın da (2007) belirttiği gibi tasarım jürileri, karşılıklı iki güç arasındaki amaç ve güç ilişkileri bakımından eşitsizlikler içeren iletişim sürecidir. İletişimi belirleyen jüri üyelerinin hegemonyasıdır ve uzman üyelerin beklentileri esas alınarak jüri sunumu stratejik olarak planlanmalıdır. $\mathrm{Bu}$ nedenle jüriye hitap etmeye başlayan öğrenci öncelikle projesinde ne yaptığını açıkça ifade etmelidir. Bu anlatıda öznel vurgulardan kaçınmalı, sürecin başı değil 'sonucu' hemen söylenmelidir. Sözel olarak tasarımın özü ve özeti bir veya en çok iki cümle ile anlatılmalıdır. Bu önermede ürün ya da yapıtın temel özellikleri ve onu diğerlerinden ayıran karakteri ortaya konulmalıdır.

$\mathrm{Bu}$ giriş, teorik çerçevede değinilen retorik öğelerden ethos dikkate alınarak değerlendirildiğinde, öğrencinin kendine güvenen ve ne yaptığını bilen bir kişilik sergilemesi bakımından etkili olacaktır. Rasyonel ve objektif bir dil ile giriş yapılması söz söyleyenin inandırıcılığını da arttıracaktır. Ayrıca bir ya da en çok iki cümle ile tasarım fikrinin özünün açıklanması inandırıcı bir kanıt olarak (logos) zihinlerde yer edecektir. Son olarak bu kendinden emin ve net giriş gerçekten faydalı bir iş yapıldığına dair jüriyi olumlu duygu durumuna sokma (pathos) potansiyeline sahiptir.

Jüri konuşmasına başlayan öğrencinin sözel olarak ortaya koyduğu özgün tasarım fikrinin görsel olarak nasıl bir ürün ya da yapıtta vücut bulduğunu görmek ister. Bu nedenle 
konuşmacının sözlerine etkili görsel kanıtların eşlik etmesi gerekir. Grafik tasarımda ilk göze çarpan ürün ya da yapıtın kendini en iyi ifade eden bakış açısı ile gösterilmesi olacaktır. ürün tasarımından örnek vermek gerekirse tasarlanan ürünün en etkileyici ve özgün karakterini açıklayan perspektif görünüşünün sunuma öncülük etmesi gerekir. Bunu bir ürünün reklam afişi gibi düşünebiliriz; fikri satacak etkileyici görsel tasarım sergilenmelidir. Şekil 1'de görülebileceği gibi bu amaçla etkili tek bir imaj kullanılabileceği gibi, ürüninsan ilişkisini, mekanik işlevini ya da çevresiyle etkileşimini açıklayan detaylar kompozisyona dahil edilebilir.

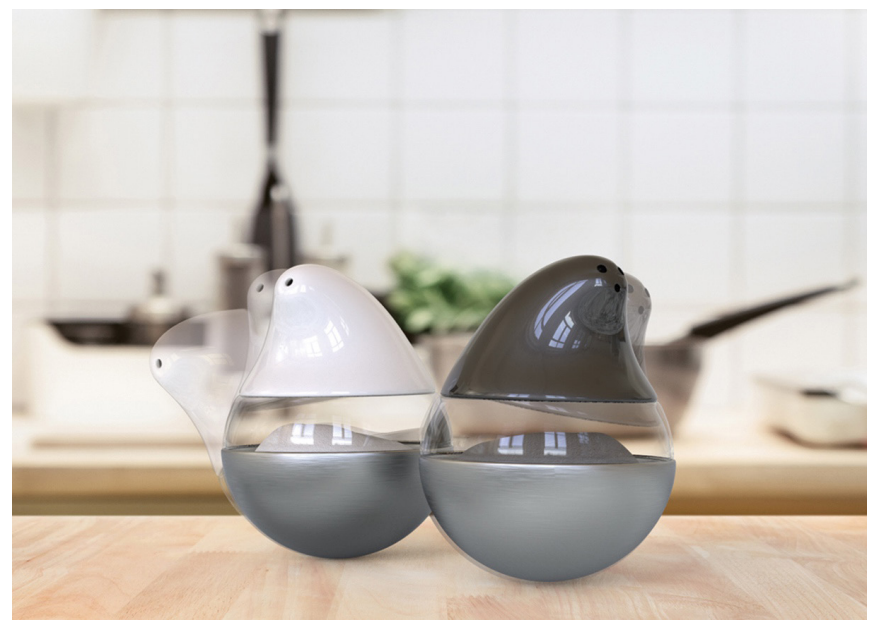

Şekil 1. Humpty Dumpty: Hacıyatmaz tuzluk ve biberlik.

(Toros ve Çakın, 2019)

\section{Neden Yaptım?}

Öğrenciler görsel ve sözel sunumları ile jürinin yönünü ve yönelimlerini belirler. Çoğu zaman bunun farkında olmasalar da kullandıkları retorik ile jüriyi belirli bir bakış açısına sokarlar. Dinleyiciler sunumda söz edilen konular üzerine düşünmeye ve sözel olarak verilen kanıtların izlerini görsellerde aramaya başlarlar. Bu nedenle ne yapıldığının açık bir şekilde ifade edilmesinin hemen ardından tasarımın gerekçesi olan nedenlerin sırasıyla ortaya konması gerekir. Böylelikle, yeni bir tasarıma neden ihtiyaç duyulduğu anlaşılabilecek ve tasarımcının bakış açısı kavranabilecektir.

Çoğu zaman projelerin konusu verildiğinde tasarım problemleri örtüktür, başka bir deyişle tasarımcı aşikâr olanın ötesine geçerek çözmeye karar verdiği tasarım problemini kendi belirler. Bunun için bazen sezgisel (Schön, 1988) bazen bilimsel araştırma (Muratovski, 2016) bazen de her ikisini birden (Cross, 1999) kullanır. Bu safhada geçerli tüm kanıtları sunmalı ve jürinin söz konusu gereksinime ikna etmelidir. Sunulan tasarımın gerekli olduğuna inanılması projenin başarılı sonuçlanabilmesinin kilit adımıdır. Bu nedenle kendi bakış açısını ve tasarım fikrinin kaynağını kanıtlar ile göstermeli, neden yaptım sorusunu kapsamlı biçimde, tüm ayrıntıları ile açıklamalıdır. Ancak bu şekilde konusunda uzman olanları yeni düşüncelere inanmaya teşvik edebilir. Öğrenci, projesinde üstesinden gelemediği sorunların ve önerdiği tasarımın zayıf yönlerinin farkındadır. Ancak bunların yanında kendisinin gözden kaçırdığı veya tasarıma hiç dahil etmediği beklentiler de olabileceğini bilir. Öğrencinin amacı jüriyi olabildiğince kendi bakış açısından konuya bakmalarını sağlayarak doğru kanıtlar ile tasarımın iyiliğine ikna etmek olacaktır.

Retorik anlatıda belki de en önemli kabul edilen logos (McCormack, 2014) bu aşamada başarılı biçimde kullanılmalıdır. Sözel ve görsel kanıtlar ile tasarımın mantığı inşa edilerek ikna edilmek istenen hakikat meşrulaştırılır (Buchanan, 1985). Bu amaçla öğrencinin tasarımı kimin için yaptığını, ürün ya da yapıtın hangi giderilememiş gereksinimleri karşılayacağını detaylı biçimde açıklaması gerekir. Bunun için sunacağı kanıtlar mevcut ürünlerin analizi, kullanım senaryoları ve kullanıcı odaklı araştırmalar olmalıdır. Bu kanıtlar tasarım yoluyla akılcı çözümler üretildiğine jüriyi inandıracaktır.

Sözel retorik, görsel tasarım diline dönüştürülmeli ve çözümlenmeye çalışılan tasarım problemi uygun çizimlerle sergilenmelidir. Şekil 2'de, bu bağlamda, endüstri ürünleri tasarımı sunumları için hazırlanmış grafik tasarımlar örnek olarak gösterilebilir.

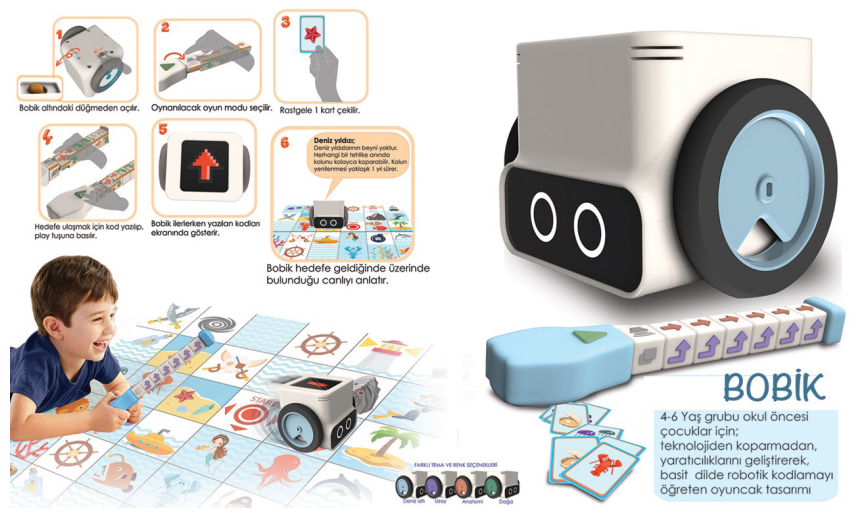

Şekil 2. Bobik, 4-6 yaş çocuklar için oyuncak. (Açıkbaş, 2019) 
Çok iyi bilindiği gibi tasarımın her alanında geçerli iletişim dili görsel öğeler üzerinden gerçekleşir ve paftalar ile üç boyutlu modeller, tasarım jürilerinde kilit önem taşır. Öncelikle sunulan tasarımı ya da yapıtı, yaratıcılık ve özgünlük bağlamında jüri üyelerine en etkili anlatacak teknikler kullanılmalıdır. Bir tasarım projesinin olmazsa olmazı olan ürün ya da yapıtın üç boyutlu görüntüsü, insan ve veya mekân bağlamında konumlandırılması, fonksiyonlarını açıklayan kullanım senaryosu ve gerekli teknik çizimleri paftalarda bulunmalıdır.

Paftalarda yer alan çizimlerde kullanılan görseller olabildiğince kaliteli, yüksek çözünürlükte ve okunaklı olmalıdır. Jürinin izleme mesafesi dikkate alınarak görsel öğelerin büyüklükleri ile figür zemin ilişkisi doğru planlanmalıdır. Özellikle uyum, hiyerarşi ve denge gibi temel tasarım ilkleri, görsel iletişim tasarımında dikkatlice uygulanmalıdır. Ayrıca tipografi ve renk seçimleri, okunaklılık ve etkileyicilik göz önünde bulundurularak yapılmalıdır. Paftalarda kullanılan sözel bilgilerde ise yazım kurallarına uyulmalı, uygun terminolojiler ve akıcı bir anlatım dilinin kullanıldığından emin olunmalıdır.

'Neden yaptım?' kanıtlar ile açıklanırken bir yandan da tasarımın amacı ve özgün yapıtın değeri verilir. Bu söylevde tasarımcı olarak benimsenen öznel bakış açısı da sunulmuş olur. Bu nedenle duygulara hitap edilmesi ve retoriğin pathos öğesinin etkili biçimde sunumda kullanılması gerekir. Aristoteles'e göre ikna, akıl ve beyinden geçerek elde edilebileceği gibi kalpten de gelebilir (McCormack, 2014). Duyguların, alınan kararlar üzerinde etkili olduğu da hesaba katıldığında jüri üyelerinin olumlu ruh haline sokulabilmesi önemlidir.

$\mathrm{Bu}$ amaçla doğru ve etkili hislerin uyarılması gerekir. $\mathrm{Bu}$ noktada teorik çerçevede bahsedilen duygusal ikna önermelerini hatırlamak da fayda var. Hitap edilen jüri üyelerinin farklı karakter ve özgeçmişlere sahip uzmanlar oldukları ve her biri için ayrı stratejik söylem geliştirmenin yararsız bir çaba olacağı dikkate alındığında, jüriye ortak özellikler taşıyan bir topluluk olarak yaklaşmak gerekir. Mesleklerinde uzman olan akademisyen ve profesyonellerden oluşan bu topluluk için ortak değerler keşfedilmeli ve tamamı etkileyebilecek söylemler geliştirilmelidir. Tasarım alanı odağa konulduğunda, klasik ve çağdaş tasarım düşünceleri, profesyonel mesleğe ilişkin etik yaklaşımlar ve hem evrensel hem kültürel değerler bilinmeli ve bunlar coşku ve taktir duygularını güdülemek için kullanılmalıdır.

Neden yaptığını anlatırken öğrenci bir yandan da karakteri ile ilgili izler bırakır. Retoriğin ethos öğesini ve konuşmacının kişiliğinin ikna üzerinde doğrudan etkisi olduğunu unutmamak gerekir. Bu nedenle öğrenci, konun gelişme safhası olan bu aşamada güçlü ve etkili bir karakter sergilemelidir. Özellikle sunum sırasında öğrenci, tasarım problemini işaret eden kanıtlar sunarken insanlık ve toplum bilincini de ortaya koyan söylem kullanmalıdır. Tasarımcı olarak sadece ürünün formunu değil onun kullanım biçimi ile kültürleri de şekillendirdiğinin farkında olduğunu yansıtmalıdır. Toplum ve insan sorunları ile empati kuran, mesleki idrak düzeyi yüksek, iyi niyetli ve güvenilir bir kişilik olduğuna jüriyi ikna etmelidir.

\section{Nasıl Yaptım?}

Ne yaptığını ve neden yaptığını açıklayan öğrenci sunumun sonunda tasarımını nasıl yaptığını anlatmalıdır. Bu anlatıda yine logos, pathos ve ethos öğelerine ilişkin ikna yolları dikkatlice sunuma adapte edilmelidir. Öncelikle iyiliği ve değeri bir önceki bölümde kanıtlanan tasarım fikrinin üretilebilir ve uygulanabilir ${ }^{4}$ oluşu akla yatkın biçimde ve teknik olarak tarif edilmelidir (Buchanan, 1985). Aristoteles (2004, s. 132), ikna için olanaklı ya da olanaksız oluşun tartışılması gerektiğini vurgular: “.. çünkü kural olarak hiç kimse imkânsızlıkları sevmez, arzu etmez. Herhangi bir bilimin ya da sanatın nesnesi olan şeyler mümkündür ve vardır ya da var olabilir."

Bu sırada doğru terminoloji ve mesleki bilgiler ile donanmış bir dil kullanılmalıdır. Sözel bilgiye eşlik eden görsel sunumlarda Şekil 3 ve 4'de (Karadağ, 2019) gösterildiği gibi teknik çizimler, detaylar, malzemeler ve üretim yöntemleri ile kullanılan teknolojiler verilmelidir. Öğrencinin yaptığı teknik açıklamalar gerekli mesleki donanıma sahip olduğunu gösterir. Bu sunumları yapabilen öğrenci, işini ve mesleğini iyi bilen biri olarak algılanacak, ehil ve sözüne güvenilebilecek bir kişilik olarak takdir görecektir.

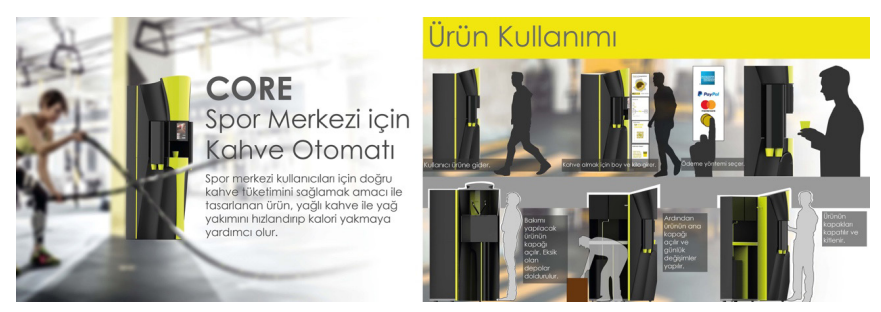

Şekil 3. Core, yeni nesil kahve makinesi. (Karadağ, 2019)

4 Tasarımda zaman zaman verilen kavramsal projelerde, mevcut toplumsal, teknolojik ve bilimsel sistemin ötesine geçmesi gereken bir kurgu istenebilir. Bu durumda dahi, projelerin sınırılıkları dahilinde ürün ya da yapıtın nasıl yapılıp uygulanacağına dair kanıtların sunulması gerekir. 


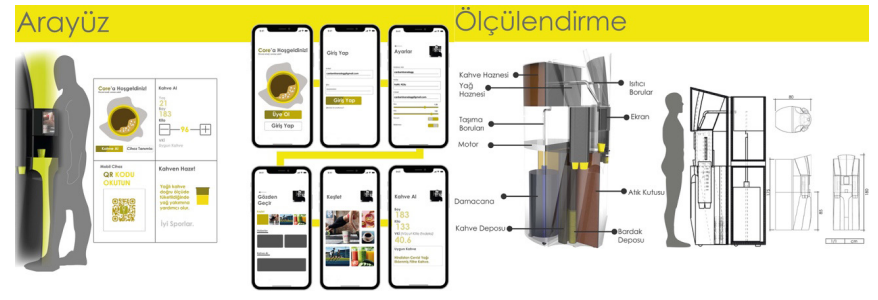

Şekil 4. Core, yeni nesil kahve makinesi. (Karadağ, 2019)

Ancak, zaman zaman öğrenciler kendileri ve kişilikleri ile sundukları tasarımı özdeşleştirirler ve neredeyse bir tutarlar. Bu da gelen eleştirilerin ürün ya da yapıttan ziyade kendilerine yönlendirildiği hissine yol açar. Bu ruh durumu objektif anlatımı zedeleyebilir ve savunmanın kişileşmesine neden olabilir. Oysa jüri karşısında henüz öğrenme sürecinde olan, deneyimsiz tasarımcılar bulunduğunun farkındadır; çoğu durumda tasarım fikirlerinin nasıl yapılacağına dair tam ve kesin cevapların verilememesini anlayışla karşılayacak olgunluktadır. Elbette yine de uzman jüri üyeleri, mesleki gereklilikler ve sorumluluklar konusunda farkındalık oluşturulması için bu aşamada detaylı soru ve eleştiriler yöneltirler ve karşılarında öğrenmeye açık, dinleyen ancak kendini savunabilen, kararlı öğrenciler görmek isterler.

Öğrencilerin özellikle yıpratıcı ve yorucu geçen sunumun bu son aşamasında, jüri üyelerinin uzmanlıkları ve tecrübelerinden dolayı ve öğrenci projelerini değerlendirmek için orada bulunduklarını hatırlamaları gerekir. İkna çatışma ve öfkeden değil karşılıklı anlayış geliştirme ve yapıcı diyalektikten beslenmelidir.

Yukarıda tasarım jürisi süreci dikkate alınarak, retorik iletişim üç kısımda detaylı biçimde incelenmiştir. Bundan sonraki kısımda ve çalışmanın sonucuna gelmeden nihai ve genel öneriler sunulacaktır.

\section{Nihai ve Genel Öneriler}

Tasarım jürileri, öğrencilerin başa çıkması gereken önemli ve zorlu etkinliklerdir. Bu konudaki becerilerini geliştirmeleri hem öğrencilik hem de mesleki hayatlarında muvaffakiyetlerini olumlu yönde etkileyecektir. Bu nedenle bir kez daha tüm evreler için geçerli olacak birkaç öneriyi daha sırlamak yerinde olacaktır.

Projenin geliştirilmesi ve gerekli çizim ve maketlerin hazırlanması için yüksek tempoda geçen son günlerin ardından öğrenciler jüriye genellikle yorgun ve yıpranmış olarak gelirler. Tipik olarak öğrenciler tasarımlarının iki ve üç boyutlu çizim ve maketlerine odaklandıkları için sözel anlatıma ya da sunumun bütününe sınırlı ya da yetersiz ilgi gösterirler. Zira öğrenciler uzun stüdyo kritikleri sırasında defalarca projesini anlatmış, sunmuş ve tasarımı ile ilgili pek çok eleştiriyle hali hazırda karşılaşmıştır. Ancak jürideki anlatım ve karşııklı iletişim stüdyo derslerindeki kritik alma sürecinden oldukça farklıdır ve planlanması gerekir.

Öncelikle sunum görsel ve sözel öğeleri ile birlikte baştan sona planlanmalıdır. Bu çalışmada, tasarım alanında alışı ımış olanın aksine, ilk olarak sözel sunumun hazırlanması tavsiye edilir; daha sonra görsel kompozisyon buna uygun olarak tasarlanmalıdır. Sözel metin olabildiğince anlaşılır ve sade bir dil ile kaleme alınmalıdır. Etkili bir sözel anlatım için gerekli olan her şey söylenmeli, gereksiz olanlardan kurtulmalı ve özellikle tekrarlardan kaçınılmalıdır.

Paftalar sözel anlatıma uyumlu, anlatılanların sırasına hiyerarşik olarak uygun biçimde tasarlanmalıdır. Sözel sunumdaki temel önermeler, görsel dile eşlik edecek şekilde grafikanlatımdakullanılmalıdır.Zirasunumungerçekleşmemesi ya da kapalı jüri olarak adlandırılan öğrencinin bulunmadığı bir ortamda projenin değerlendirilmesi durumunda eksiksiz bilginin paftalarda bulunması gerekir. Sözel anlatıda olduğu gibi görsel iletişimin de sade ve anlaşılır olmasına özen gösterilmelidir. En az öğe ile kendini ifade edebilen sunumlar hazırlanmalıdır; teknik olarak gerekli tüm çizimler konulmalı, gereksiz desen, süslemeler, tekrar ve ilgisiz öğelerden kaçınılmalıdır.

Bütün sunum planlandıktan sonra özellikle sözel metin en az birkaç kez prova edilmeli ve anlatılanların sırası ve süresi kontrol edilmelidir. Mümkünse öğrenci sunumunu başkalarının önünde prova etmeli ve aldığı geri bildirimler ile gerekli gördüğü güncellemeleri yapmalıdır. Bu, aynı zamanda, sunumun akıcılığını arttıracak ve olası dil sürçmeleri ve hataları da azaltacaktır.

Öğrencilerin sunum sırasında olabildiğince akıcı ve anlaşılır bir dil kullanması gerekir. Bunun için uzun ve karmaşık cümleler yerine kısa, sade ve dilbilgisi kurallarına uygun cümleler kullanılması önerilir. Bu konuşmada teknik terminolojiler yerli yerinde kullanılmalı ve her bir kelime doğru telaffuz edilmelidir. Öğrencilerin bazı kelimelerde zorlanmaları durumunda konuşmanın söz konusu kısmını yazmaları ve kâğıttan okumaları uygun olacaktır. Ancak bir sunumun baştan sona kâğıttan okunması jüri üzerinde olumsuz etki yaratabilir. Öncelikle bu tarz sunumlar öğrencinin konusuna hakimiyeti ile ilgili şüphe yaratabilir. 
Dahası anlatıcının dinleyiciler ile göz temasını engelleyecek bu da jüri ile empati kurulmasını zorlaştıracaktır.

Her ne kadar jürinin odağında ürün ya da eser bulunsa da sunum yapanın dış görünüşü de dinleyiciler için etkili olmaktadır. Öncelikle jüri günü giyilecekler, sunumunun önemini ve jüriye verilen değeri yansıtacak biçimde seçilmelidir. Burada her vaka için geçerli olabilecek mutlak ve kusursuz bir önerme yapmak doğru olmaz. Genellikle temiz, özenli, proje konusu ile uyumlu ve verilmek istenen tasarımcı kişiliğini yansıtan kıyafetler seçilmelidir. Bazı projelerde ise tasarlanan ürünün karakterine uygun giyinilmesi jüri üzerinde olumlu etki gösterebilir; örneğin balıkçılar için sırt çantası tasarımında balıkçı kıyafetleri giyerek üretilen maket ya da prototipin kullanım halinde gösterilmesi gibi.

Önerilerin ardından, son olarak birkaç uyarıyı da sıralamak gerekir. Tasarım jürileri özgün ve yeni fikirler ile bezenen projelerin bitişinin kutlaması niteliğini taşır (Frederickson, 1990). Bu şölen etik olmayan girişimler ve uygulamalar ile bozulmamalıdır. Öğrenciler tasarımlarında ve sunumlarında asla kendilerine ait olmayan fikir ve çizimleri kullanmamalıdır. Alıntı ya da esin kaynakları var ise bunlara referans verilmesi ve açıkça orijinlerinin ifşa edilmesi gerekir. Söz söyleyene güvenin sarsılması tasarım ve proje konusundaki tüm ikna çabalarını boşa çıkaracak ve uzlaşmanın önünü tıkayacaktır.

Bir başka kaçınılması gereken davranış ise tasarım sürecinde stüdyo derslerine giren akademisyenlere referans vermektir. Daha açık bir ifade ile gelen eleştiriler karşısında savunmayı ders yürütücülerinin ardına gizlenerek yapmaya çalışmaktır. Bu davranışlar hem sorumluluğu üzerinden atma çabası olarak görülme hem de jüri üyeleri arasında gerginlik yaratma potansiyeline sahiptir. Elbette proje ve tasarım fikirleri, stüdyo dersleri sırasında öğretmenler ile öğrenci arasındaki usta-çırak ilişsisi ile şekillenmiştir (Schön, 1985). Ancak, tasarım süreci her ne kadar deneyimli akademisyen ve profesyonellerce yönlendirilse de nihai kararlar öğrenci tarafından verilir ve tasarımcı öğrencinin ürünü veya yapıtı üzerindeki tüm sorumluluğu alması beklenir.

Yukarıda jüri iletişiminde dikkat edilmesi gereken unsurlara oldukça kapsamlı biçimde değinilmeye çalışılmışıdır. Söz konusu öneri ve uyarıların, bir önceki bölümde çalışmanın özgün önerisi olarak sunulan retorik modele adapte edilmesi faydalı olacaktır.

\section{Sonuç}

$\mathrm{Bu}$ çalışmada, Aristoteles'in retorik teorileri kullanılarak tasarım jürileri için bir iletişim model önerilmiştir. Modelin amacı, sözel ve görsel anlatımın etkili biçimde kullanılması gereken jüriler için öğrencilere sistemli bir yol önermektir. Önerilen yapı ve ikna öğeleri mimarlıktan endüstri ürünleri tasarımı, modandan grafik tasarımına kadar tüm tasarım alanındaki sunumlara adapte dilebilir niteliktedir. Ayrıca temel ikna öğelerini içeren yöntem her öğrencinin özgün, öznel ve yaratıcı yorumlar ile geliştirilebilir durumdadır.

Öğrenci merkezi bakış açısının benimsendiği bu çalışma, tasarım öğrencilerinin sunum ve ikna becerilerini geliştirmelerinde faydalı olacaktır. Ayrıca akademik ilginin kısıtlı olduğu 'jüri ve ikna iletişimi’ konusunda alan yazınına da katkıda bulunmaktadır. Yeni ve işlevsel olduğu düşünülen bir yöntem önerisi sunması bakımından yeni akademik çalışmalara ilham kaynağı olacağı düşünülmektedir. Bundan sonraki araştırmalarda çeşitli tasarım okullarında ve farklı disiplinlerden öğrenciler ile model denenebilir. Ayrıca farklı teorik çerçeveleri temel alan bilimsel çalışmalarda model ve ikna iletişimi geliştirilebilir ve tasarım eğitimi ile tasarım öğrencilerinin akademik başarısına katkı sağlanacak yeni yollar keşfedilebilir.

\section{Kaynakça}

Açıkbaş, B. (2019). Bobik. (Mezuniyet projesi). Atılım Üniversitesi Endüstri Ürünleri Tasarımı Bölümü, Ankara.

Aristoteles. (2004). Retorik (Çev. M. H. Doğan). İstanbul: Y.K.Y.

Buchanan, R. (1985). Declaration by design: Rhetoric, argument, and demonstration in design practice. Design Issues, 2(1), 4. https://doi.org/10.2307/1511524

Cross, N. (1999). Design research: A disciplined conversation. Design Issues, 15(2), 5-10.

Daroda, K. S. (2011). Verbal technical presentation skill improvement requirements for architects in Nigeria. Journal of Research in Education and Society, 2(2), 144-153.

Frederickson, M. P. (1990). Design juries: a study in lines of communication. Journal of Architectural Education, 43(2), 22 27. https://doi.org/10.1080/10464883.1990.10758556

Gurel, M. 0., ve Basa, I. (2004). The status of graphical presentation in interior/architectural design education. International Journal of Art and Design Education, 23(2), 192206. https://doi.org/10.1111/j.1476-8070.2004.00397.x 
Heath, R. L. (2004). Halkla ilişkiler için retoriksel bir uygulama. H. Güz ve S. Y. Becerikli (Ed.), Halkla İlişkilerde Seçme Yazılar içinde (s. 107-154). Ankara: Alban Tanıtım.

Ilgaz, A. (2009). Design juries as a means of assessment and criticism in industrial design education: A Study on Metu Department of Industrial Design. (Yayımlanmamış yüksek lisans tezi). METU, Ankara.

Ilgaz, A., ve Korkut, F. (2013). Öğrencilerin ve değerlendirenlerin bakış açılarından endüstri ürünleri tasarımı eğitiminde jüri değerlendirmesi. Y. Sarıkaya Levent, M. Uçar (Ed.). Mersin'den mimarlık planlama tasarım yazıları: Tamer Gök'e armağan içinde (s. 203-221). Mersin: Mersin Üniversitesi Yayınları.

Karadağ, C. (2019). Core. Atılım Üniversitesi Endüstri Ürünleri Tasarımı Bölümü, 3. Sınıf Projesi.

Kaufer, D. S., ve Butler, B. S. (2013). Rhetoric and the art of design. New York: Routledge.

L'Etang, J. (2002). Halkla ilişkiler ve retorik. J. L'Etang ve M. Pieczka (Ed.), Halkla ilişkilerde eleştirel yaklaşımlar içinde (s. 189-213). Ankara: Vadi Yayınları.

McCormack, K. C. (2014). Ethos, pathos, and logos: The benefits of Aristotelian rhetoric in the courtroom. Washington University Jurisprudence Review, 131(1), 131-155. Erişim adresi: http:// openscholarship.wustl.edu/law_jurisprudence/vol7/iss1/9

Muratovski, G. (2016). Research for designers: A guide to methods and practice. SAGE Publications.

Schön, D. (1985). The design studio: An exploration of its traditions and potentials. International Specialized Book Service Incorporated.

(1988). Toward a marriage of artistry \& applied science in the architectural design studio. Journal of Architectural Education, 41(4), 4-10. https://doi.org/10.1080/10464883. 1988.10758496

Toros, S., ve Çakın Ç. (2019). Humpty Dumpty. Musedesign Awards, Product Design Category, Rose Gold Winner. Retrieved from: https://design.museaward.com/winner-info.php?id=470

Webster, H. (2006). A Foucauldian look at the design jury. Art, Design \& Communication in Higher Education, 5(1), 5-19. https://doi.org/10.1386/adch.5.1.5_1

- (2007). The analytics of power: Re-presenting the design jury. Journal of Architectural Education, 60(3), 21-27. 